\title{
Effect of osmotic stress on the formation of a population of polysomes and their stability in pea (Pisum sativum L.) seeds
}

\author{
Wioletta Brosowska-Arendt $\cdot$ Stanisław Weidner
}

Received: 29 March 2010/Revised: 10 November 2010/Accepted: 1 December 2010/Published online: 13 January 2011

(C) The Author(s) 2011. This article is published with open access at Springerlink.com

\begin{abstract}
Plants growing under natural conditions are constantly exposed to various stress factors, which can restrain their productivity and limit yields. This paper deals with the effect of long- and short-term osmotic stress followed by recovery on the formation of polysomes and their stability during germination of pea (Pisum sativum L.) seeds. By isolating polysomes, it is possible to obtain an index which evidences the ability of tissues to synthesize proteins. Changes in the distribution of polysomes often precede measurable changes in amounts of proteins. Under osmotic stress, the dominant population of polysomes was the population of free polysomes (FP). The share of membrane-bound polysomes (MBP) and cytoskeletonbound polysomes (CBP) and cytoskeleton-membranebound polysomes (CMBP) in the total fraction of ribosomes increased under intensive $(-1.0$ and $-1.5 \mathrm{MPa})$ osmotic stress. These results can suggest that the bound forms of polysomes play an important role in the synthesis of stress proteins. In addition, the stability of polysomes isolated from pea early seedlings growing under unstressed control and osmotic stress conditions was tested. It turned out that polysomes formed under osmotic stress conditions (especially the CMBP) were more resistant to the activity of exogenous ribonucleases than the polysomes in the control samples. Under stress conditions it is highly likely that ribosomes become more densely packed on mRNA
\end{abstract}

Communicated by S. Abe.

W. Brosowska-Arendt $(\bowtie) \cdot$ S. Weidner Department of Biochemistry, Faculty of Biology, University of Warmia and Mazury in Olsztyn, M. Oczapowskiego St. 1A, 10-957 Olsztyn-Kortowo, Poland e-mail: wioletta.brosowska@uwm.edu.pl thus making it more resistant to ribonuclease. This is just one of the many mechanisms regulating stability of mRNA.

Keywords Cytoskeleton-membrane-bound polysomes . Germination · Pea seeds · Pisum sativum L. · Polysome stability · Osmotic stress

$\begin{array}{ll}\text { Abbreviations } \\ \text { CBP } & \text { Cytoskeleton-bound polysomes } \\ \text { CMBP } & \text { Cytoskeleton-membrane-bound polysomes } \\ \text { EGTA } & \begin{array}{l}\text { Ethylene glycol-bis (aminoethyl ether) } \\ \text { N,N, } N^{\prime \prime}, \mathrm{N}^{\prime \prime} \text {-tetraacetic acid }\end{array} \\ \text { FP } & \text { Free polysomes } \\ \text { HEPES } & \text { N-2-hydroxyethylpiperazine- } \mathrm{N}^{\prime \prime} \text {-2- } \\ & \text { ethanesulfonic acid } \\ \text { KOAc } & \text { Potassium acetate } \\ \text { MBP } & \text { Membrane-bound polysomes } \\ \text { Mg(OAc) } & \text { Magnesium acetate } \\ \text { PEG } & \text { Polyethylene glycol } \\ \text { PMSF } & \text { Phenylmethylsulfonyl fluoride } \\ \text { RNase } & \text { Ribonuclease }\end{array}$

Introduction

Plants growing under natural conditions are exposed to the effects produced by various environmental factors, whichwhen reaching certain intensity and affecting plants for a long time to disrupt normal development and metabolism of plants, thus reducing their productivity and yields (Starck et al. 1995). The actual response to environmental stress depends on the developmental phase and the physiological activity of the plant. Thus, the protective mechanisms are initiated more easily in young plants, with a more intensive 
metabolism, than in older plants (Starck 2002). The response of plants to drought will vary depending on a plant species, intensity of the stress and its duration (Mullet and Whitsitt 1996). Should a stress factor be very intensive or prolonged, the initial, reversible effects can turn into irreversible ones (Kacperska 1998; Starck 2002).

Osmotic stress can be caused by different stress factors, such as shortage of water, extreme temperatures or excessive salinity. Among the earliest metabolic changes caused by water stress is a depressed share of polysomes (Hsiao 1970). Following disaggregation of polysomes, the growth of a plant becomes retarded due to a decreased rate of protein synthesis (Hsiao 1970; Mason et al. 1988). The largest share in the total pool of polysomes belongs to the population of cytoskeleton-bound polysomes (CBP), which can reach up to $70 \%$ of the total polysome content (Abe and Davies 1991). Davies et al. (1998) found that the translation process on CBP and cytoskeleton-membranebound polysomes (CMBP) is faster than on free polysomes (FP) or membrane-bound polysomes (MBP). According to Weidner et al. (2000), most ${ }^{14} \mathrm{C}$-amino-acids are incorporated into a newly formed polypeptide chain, which is synthesized with an aid of no other polysomes but the CMBP population. The so-called stress proteins are synthesized on the CBP (Adams et al. 1983; Weidner et al. 2000). By assessing the contribution of polysomes to the total fraction of ribosomes, it is possible to establish how quickly a given factor affects protein synthesis. Changes in the distribution of proteins often precede any measurable changes in amounts of proteins (Weidner 2007). Water deficit also has some influence on changes in the content of mRNA in the cell (Kawaguchi et al. 2004). Thus, an important stage in plant adaptation to stress consists in proper synthesis and regulation of the stability of mRNA, as plants can be protected against adverse influence of environmental factors via synthesis of appropriate polypeptides (Weidner et al. 2006).

The objective of this study has been to demonstrate differences in the formation of polysomes and their stability in pea (Pisum sativum L.) seeds germinating under unstressed control and under osmotic stress $(-0.2 ;-0.5$; -1.0 and $-1.5 \mathrm{MPa})$ and after post-stress recovery.

\section{Materials and methods}

Plant material and germination under normal and osmotic stress conditions

Experiments were conducted on Pisum sativum L. cv. sixweek TOR seeds, supplied by Torseed S. A. (Torun, Poland). Seeds were surface disinfected in $1 \%$ sodium hypochloride for $3 \mathrm{~min}$ and then washed with tap water and sterilized water. Intact seeds were placed on Petri dishes with two layers of Whatman 2 filter paper No.1 (Whatman, Maidstone, Kent, the UK) wetted with $40 \mathrm{ml}$ distilled water and germinated in the dark at $+20^{\circ} \mathrm{C}$ for $24,48,72$ and $96 \mathrm{~h}$. After $48 \mathrm{~h}$, some of the seeds which germinated under unstressed control (distilled water) (when the roots were $\geq 1 \mathrm{~mm}$ ) were transferred for the next $24 \mathrm{~h}$ to osmotic stress conditions with different concentration of PEG, which caused decrease of osmotic potential to $-0.2,-0.5$, $-1.0,-1.5 \mathrm{MPa}$. After short-term osmotic stress, pea early seedlings were transferred again to unstressed germination conditions for the next $24 \mathrm{~h}$, which was a recovery period. Simultaneously, another batch of pea seeds was germinated under long-term osmotic stress conditions $(-0.2,-0.5$, $-1.0,-1.5 \mathrm{MPa})$ at $20^{\circ} \mathrm{C}$ for $24,48,72$ and $96 \mathrm{~h}$. After fixing the time of germination, embryos, sprouts or early seedlings (according to Gong et al. 2001) were isolated from seeds and used for further tests. All determinations were repeated three times.

Polysome isolation and quantification

The tissue $(400 \mathrm{mg}$ ) was homogenized in $3 \mathrm{ml}$ of cytoskeleton-stabilizing buffer C (Abe and Davies 1991), filtered and centrifuged at $27,000 \times g$ for $10 \mathrm{~min}$. Buffer $\mathrm{C}$ consists of $5 \mathrm{mM}$ HEPES, $10 \mathrm{mM} \mathrm{Mg}(\mathrm{OAc})_{2}, 2 \mathrm{mM}$ EGTA, $1 \mathrm{mM}$ PMSF adjusted to $\mathrm{pH} 7.5$ with $9.8 \mathrm{mM}$ $\mathrm{KOH}$. This buffer allows sequential isolation of four polysome populations (Davies and Abe 1995): FP, MBP, CBP and CMBP. The supernatant polysomes included the FP and, to prevent their degradation by RNase, the samples were adjusted to buffer $\mathrm{U}$, consisting of $200 \mathrm{mM}$ Tris- $\mathrm{HCl}$, pH 8.5, $50 \mathrm{mM} \mathrm{KOAc,} 25 \mathrm{mM} \mathrm{Mg}(\mathrm{OAc})_{2}, 2$ mM EGTA, $100 \mathrm{mg} / \mathrm{ml}$ heparin, 2\% PTE (polyoxyethylene-10-tridecyl ether, a non-ionic detergent) and $1 \%$ sodium deoxycholate (Abe et al. 1992) by adding $1 / 4 \mathrm{vol}$. of $4 \times$ concentrated buffer $U$ and held on ice prior to further processing. The remaining polysomes were in the pellet and were sequentially solubilized as follows. The pellet was resuspended in $3 \mathrm{ml}$ of buffer $\mathrm{C}+0.5 \%$ PTE to disrupt membranes, centrifuged for $10 \mathrm{~min}$ at $27,000 \times g$ to leave MBP in the supernatant (again converted to buffer $U$ to maintain polysome integrity). All other polysomes remained in the pellet. This pellet was next resuspended in $3 \mathrm{ml}$ of buffer $\mathrm{C}+200 \mathrm{mM}$ Tris- $\mathrm{HCl}, \mathrm{pH} 8.5$ to disrupt the polysomecytoskeleton interaction and centrifuged for $10 \mathrm{~min}$ at $27,000 \times g$ to leave CBP in the supernatant (again converted to buffer $\mathrm{U}$ ). The final pellet was resuspended in $4 \mathrm{ml}$ of $1 \times$ concentrated of buffer $U$ and re-centrifuged to release the CMBP. All supernatant fractions (FP, MBP, CBP, CMBP) were layered on a $0.5 \mathrm{ml}$ "pad" of $50 \%$ (w/v) sucrose in buffer B $(50 \mathrm{mM}$ Tris- $\mathrm{HCl}, \mathrm{pH} 7.5,20 \mathrm{mM}$ $\mathrm{KOAc}, 10 \mathrm{mM} \mathrm{Mg}(\mathrm{OAc})_{2}$ ) and centrifuged for $90 \mathrm{~min}$ at 
$300,000 \times g$ in Beckman 65 Ti rotor. The polysomal pellets were rinsed with water and then resuspended in $0.5 \mathrm{ml}$ of buffer $\mathrm{U}$. The resuspended polysomes were centrifuged at maximum speed (approx. $27,000 \times g$ ) for $5 \mathrm{~min}$ in a microfuge prior to layering $0.1-0.2 \mathrm{ml}$ aliquots (about 15 OD units) on linear $15-60 \%(\mathrm{w} / \mathrm{v})$ sucrose gradients in buffer B and centrifuged at $300,000 \times g$ in an SW-41 Beckman rotor for $45 \mathrm{~min}$. Gradients were next scanned at $254 \mathrm{~nm}$ on a UV-5 flow recorder (ISCO, Lincoln, NE, USA) to display subunits, monosomes and polysomes. All operations were conducted at $0-4^{\circ} \mathrm{C}$.

Embryos, sprouts or early seedlings of pea were also homogenized in buffer $U$ (Abe et al. 1992) to solubilize total polysomes. The subunits, monosomes and polysomes were purified (using 50\% sucrose pad) and the resuspended polysomes were layered on linear $15-60 \%$ sucrose gradients and centrifuged in the same way as mentioned above.

Levels of polysomes were determined by measuring the area under the polysomal profile after subtracting the gradient baseline OD (absorbance of the gradient loaded with $0.1-0.2 \mathrm{ml}$ of resuspension buffer). Quantitation of the ribosomes was done assuming that the absorbance of a $1 \%$ solution of ribosomes (measured in a cuvette with a $1 \mathrm{~cm}$ optical pat at $260 \mathrm{~nm}$ ) equals 135 (Gualerzi and Cammarano 1969).

\section{Analysis of polysomes degradation}

Total ribosomal fractions and polysomal populations (FP, MBP, CBP and CMBP) were isolated (using $\mathrm{U}$ and $\mathrm{C}$ buffers, as explained above) from pea embryonic tissues after 96 and $48 \mathrm{~h}$ seed germination under unstressed control and long-term osmotic stress $(-0.2,-0.5 \mathrm{MPa})$ conditions, respectively. The samples were treated with RNase A (0.05 $\mathrm{mg} / \mathrm{ml}$; Sigma). The polysome pellets were solubilized in $0.5 \mathrm{ml}$ of buffer $\mathrm{U}$ and centrifuged for $5 \mathrm{~min}$ at $27,000 \times g$. Polysome suspensions thus prepared were distributed into six Eppendorf tubes $(0.1 \mathrm{ml}$ each). The content of half tubes was not treated with any enzyme (control samples), whereas $0.5 \mu \mathrm{l}$ RNase A was added to the three remaining tubes (Weidner et al. 2006). After shaking, the contents of all six tubes were layered on sucrose gradients (from 15 to $60 \%$ ) and centrifuged at $300,000 \times g$ for $45 \mathrm{~min}$. After centrifugation, gradients were scanned at $254 \mathrm{~nm}$ on a UV-5 flow recorder (ISCO, Lincoln, NE, USA) to display subunits, monosomes and polysomes. All operations were conducted at $0-4^{\circ} \mathrm{C}$. Polysome profiles were analyzed and RNase-treated compared with control samples.

\section{Results}

Long-term osmotic stress delayed germination of pea seeds proportionally to its intensity. The higher the osmotic stress intensity, the stronger the retardation of seed germination. At the intensity of -1.0 and $-1.5 \mathrm{MPa}$, germination was completely inhibited (Fig. 1a). In a trial which involved transfer of pea seeds germinated under unstressed control (48 h-opt.) to osmotic stress conditions for another $24 \mathrm{~h}$ (48 h-opt. +24 h-s), further growth and development of the seeds were evidently retarded, in proportion to the intensity of the stress. It was found out that both long- and short-term osmotic stress reduced the growth of pea embryos, sprouts and early seedlings, compared to the control (Figs. 1b, 2). During recovery (48 h-opt. +24 h-s +24 h-opt.), following short-term osmotic stress (48 h-opt. +24 h-s), further growth and development of pea seedlings was resumed and the growth was demonstrably larger (Fig. 2). This growth was reversely proportional to the intensity of the short-term water stress (growth gain of $63.44 \mathrm{mg}$ following the stress of $-0.2,61.61 \mathrm{mg}$ after $-0.5,52.87 \mathrm{mg}$ after -1.0 and $46.63 \mathrm{mg}$ after $-1.5 \mathrm{MPa}$ ).

The inhibition of the germination of pea seeds under osmotic stress coincided with a depressed formation of polysomes, in proportion to the intensity of the stress
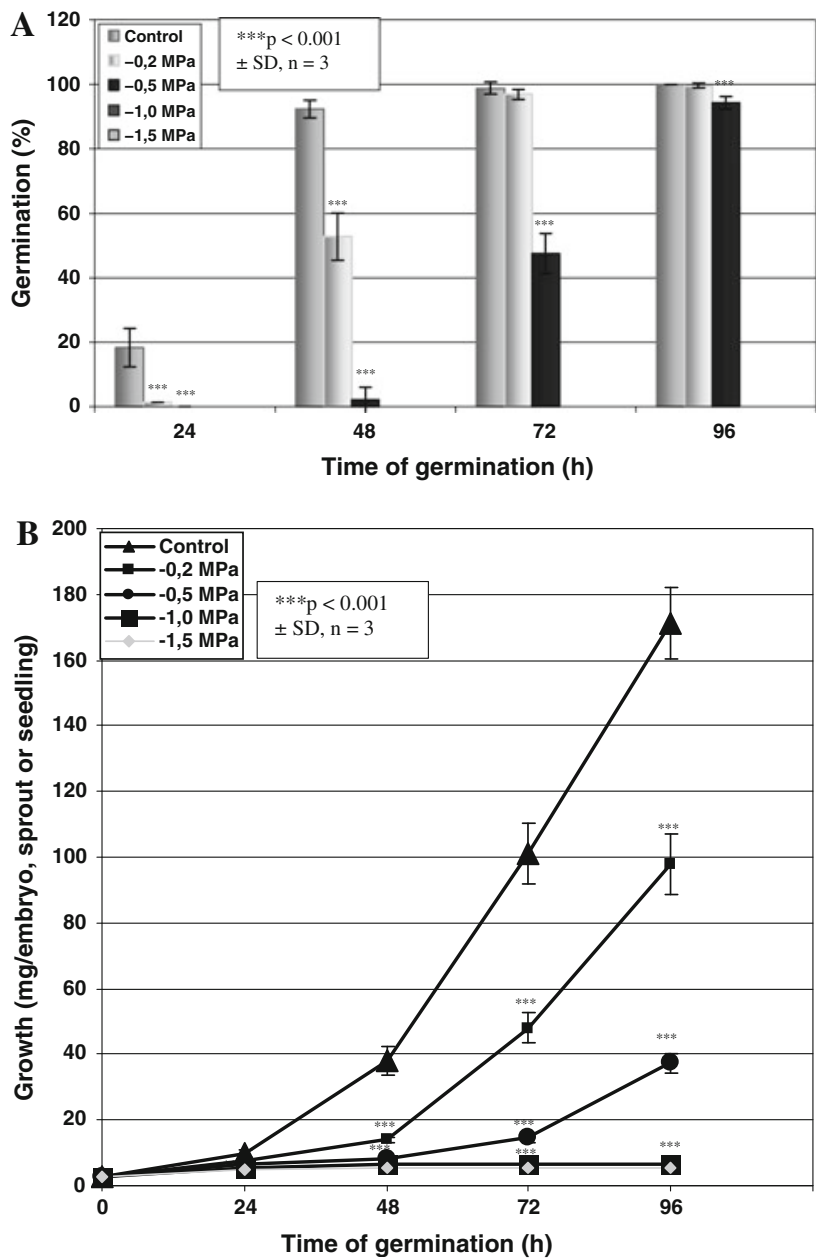

Fig. 1 Effect of long-term osmotic stress on growth of pea seedlings 


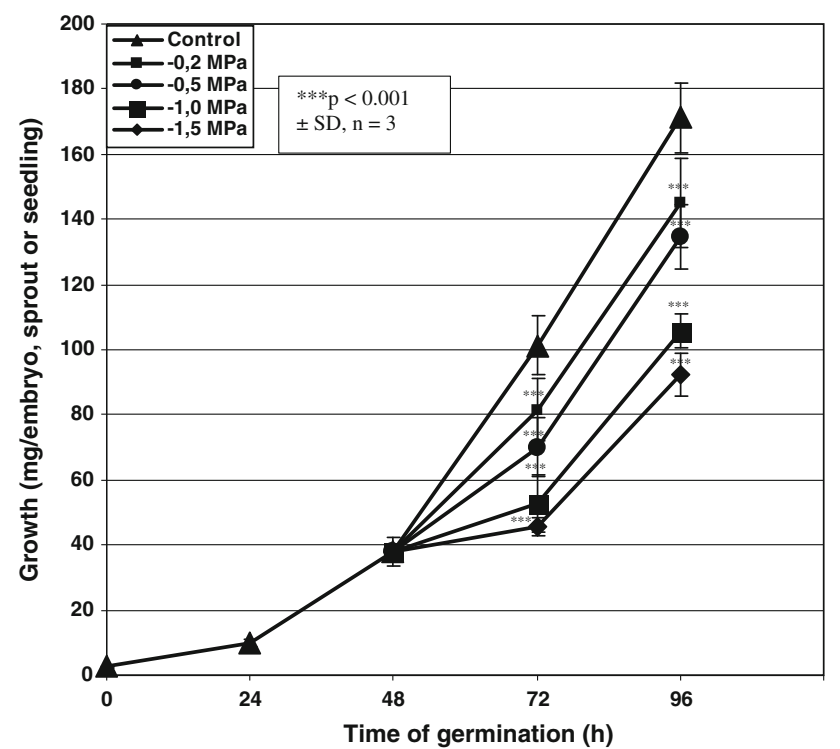

Fig. 2 Effect of short-term osmotic stress on growth of pea seedlings

during seed germination (Figs. 3, 4). This seems to indicate that under osmotic stress conditions, the general protein synthesis is depressed. The share of polysomes in the total ribosome fraction in the embryonic tissue of pea seeds germinating under long-term osmotic stress tended to decrease for the $72 \mathrm{~h}$ from the onset of the germination, after which it began to increase (except for the $-1.5 \mathrm{MPa}$

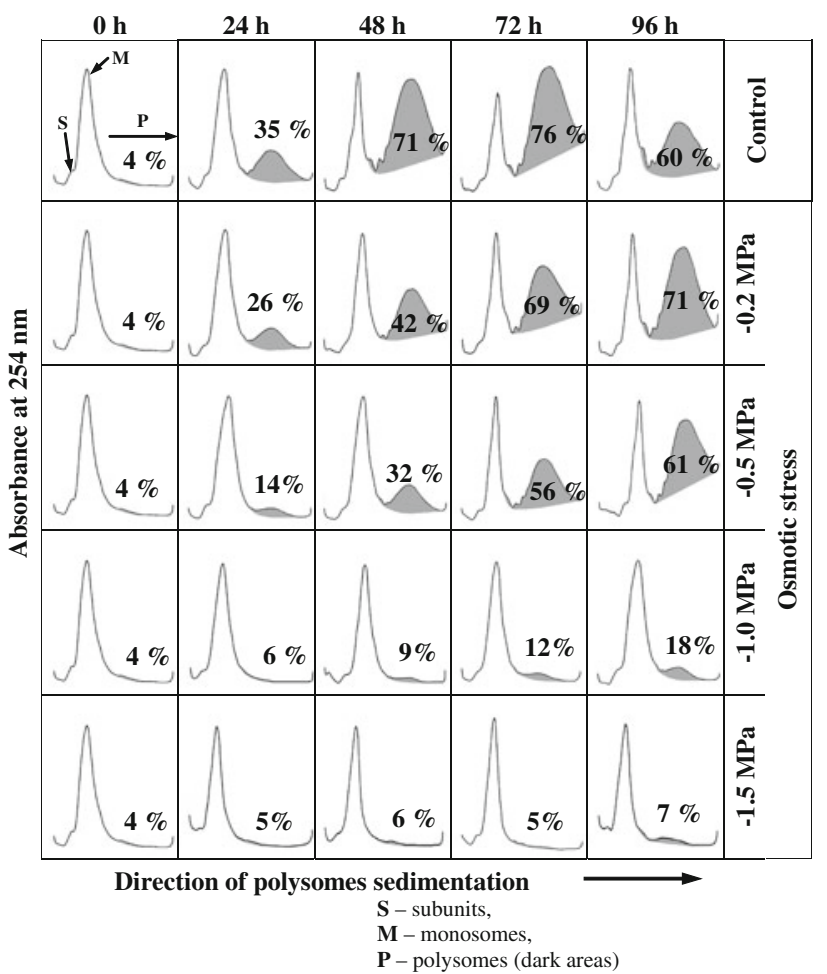

Fig. 3 Effect of osmotic stress on polysome formation in pea seedlings

\section{UNSTRESSED CONTROL}

72h-opt.
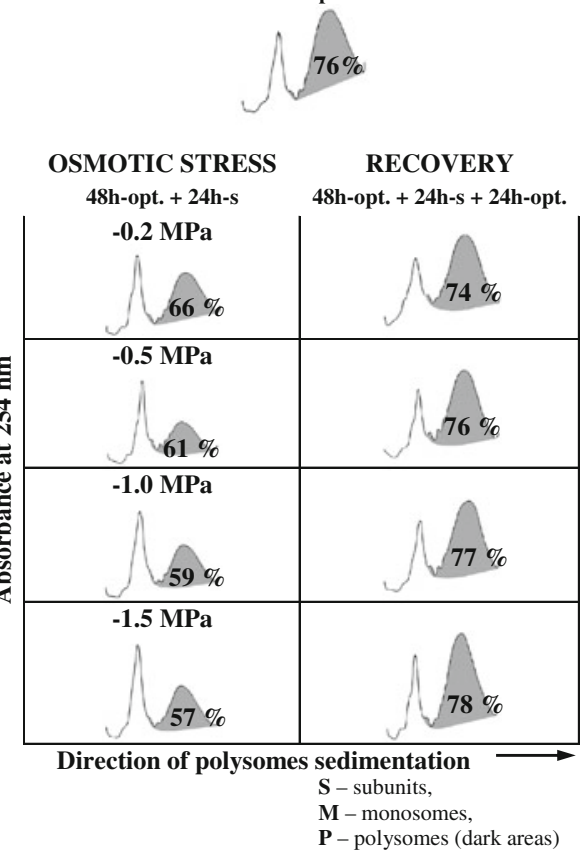

Fig. 4 Changes in polysome formation after recovery from osmotic stress

sample) as the germination progressed. This may suggest that during stress, the synthesis of the so-called stress proteins increases. Moreover, the higher the intensity of long-term osmotic stress, the greater the delay in the formation of polysomes. In the experiment involving shortterm osmotic stress, the share of polysomes in the total ribosome fraction increased in all the trials during recovery (48 h-opt. +24 h-s +24 h-opt.), i.e., after the early seedlings had been transferred from water stress conditions (48 h-opt. $+24 \mathrm{~h}$-s) to unstressed conditions. This indicates an increase in the general protein synthesis in pea seedlings which takes place during post-stress recovery. Worth noticing is the fact that formation of polysomes tended to be more intensive when the preceding short-term osmotic stress was stronger.

During the germination of pea seeds under unstressed control, the share of polysomes in the total ribosome fraction was the highest after $72 \mathrm{~h}$, after which it began to decline (Fig. 3). This may have been associated with the process of tissue aging and decreased total protein synthesis after $72 \mathrm{~h}$ of germination.

The polysomes FP, MBP, CBP and CMBP were isolated from embryos, sprouts and early seedlings after $48 \mathrm{~h}$ of seed germination under unstressed control and long-term osmotic stress conditions. It was demonstrated that the highest share of the total polysome population belonged to free polysomes (Fig. 5). Moreover, in samples exposed to long-term osmotic stress, the content of this population of 
polysomes was higher (ca. $1.78-3.97 \mathrm{mg}$ ) than in the control (ca. $0.99 \mathrm{mg}$ ). The content of the CBP and CMBP was much higher in the embryonic tissue of seeds germinating under osmotic stress (CBP from 0.41 to $0.71 \mathrm{mg}$, CMBP from 0.42 to $0.57 \mathrm{mg}$ ) than under unstressed control (CBP: $0.26 \mathrm{mg}$, CMBP: $0.16 \mathrm{mg}$ ). Having isolated the MBP, it was discovered that the content of this population in samples exposed to a low intensity stress $(-0.2$ and $-0.5 \mathrm{MPa}$ ) was lower (by ca. 0.13 and $0.09 \mathrm{mg}$, respectively), and in samples subjected to a high intensity stress $(-1.0$ and $-1.5 \mathrm{MPa})$ it was considerably larger (ca. 0.73 and $0.78 \mathrm{mg}$ ) versus the control (ca. $0.24 \mathrm{mg}$ ).

Particular fractions of polysomes (FP, MBP, CBP and CMBP) were also isolated from pea early seedlings exposed to short-term water stress and after the post-stress recovery period. It was found out that among all polysomes, free polysomes were the dominant population in the embryonic tissue of germinating pea seeds transferred from unstressed control (48 h-opt.) to short-term osmotic stress (48 h-opt. $+24 \mathrm{~h}-\mathrm{s}$ ) followed by recovery ( $48 \mathrm{~h}$ opt. +24 h-s +24 h-opt.) (Fig. 6a, b). Noteworthy is the fact that in a sample exposed to water stress of the intensity $-1.5 \mathrm{MPa}$, the content of FP population was the highest (ca. $1.40 \mathrm{mg}$ ). Populations of polysomes bound to membranes or the cytoskeleton (MBP and CBP) in the embryonic tissue of germinating pea seeds after a short-term water stress $(-0.2,-0.5,-1.0$ and $-1.5 \mathrm{MPa})$ showed a slightly increasing tendency (ca. $0.16 ; 0.21 ; 0.22$ and $0.20 \mathrm{mg}$ for MBP and ca. $0.16 ; 0.18 ; 0.19$ and $0.17 \mathrm{mg}$ for $\mathrm{CBP}$, respectively) in comparison to the control sample (ca. $0.12 \mathrm{mg}$ for MBP and $0.14 \mathrm{mg}$ for CBP). This may evidence the important role of polysome bound forms in the synthesis of the so-called stress proteins. In turn, the content of the polysomes bound with both the cytoskeleton and membranes (CMBP) was similar in all the samples (about
13-14 mg), Fig. 6a. During recovery after short-term stress (48 h-opt. +24 h-s +24 h-opt.), it was observed that the content of all polysome populations (FP, MBP, CBP and CMBP) tended to decrease compared to the samples exposed to the short-term osmotic stress only (48 h-opt. +24 h-s), Fig. 6 b.

The final stage of this research involved determination of the stability of the polysome population isolated from pea early seedlings grown under unstressed control and long-term osmotic stress $(-0.2,-0.5 \mathrm{MPa})$. The time of seed germination was chosen so that the share of polysomes in the total ribosomal material of embryonic tissues of all samples would be similar. It was determined that polysomes isolated from early seedlings of pea grown under long-term osmotic stress were more stable and more resistant to the activity of RNase than polysomes formed during seed germination under unstressed control. The share of undigested polysomes in the total ribosomal fraction was $84 \%$ at -0.2 and $97 \%$ at $-0.5 \mathrm{MPa}$, whereas under unstressed control, it was $76 \%$. Polysomes of particular populations (FP, MBP, CBP, CMBP) isolated from the embryonic tissue of pea seeds germinating during longterm osmotic stress were also more stable and more resistant to RNase than under unstressed control. The most stable one were CMBP (data not shown).

\section{Discussion}

Water availability affects many cellular processes which take place in plants, including the ones connected with germination of seeds. According to Xu and Bewley (1991), early germination stages are more sensitive to osmotic stress, which retards seed germination, development of embryos and further growth of seedlings. Such effects are
Fig. 5 Effects of osmotic stress on distribution of polysomes from different sub-cellular locations

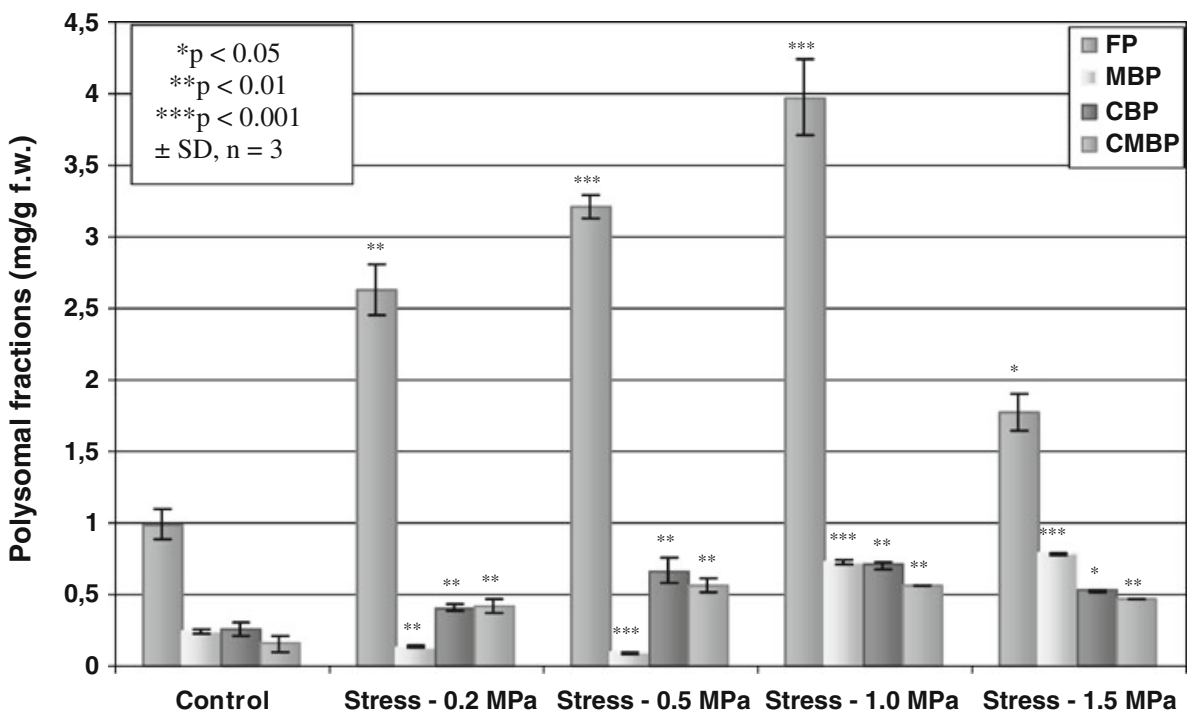


Fig. 6 Changes in distribution of polysomes after recovery from osmotic stress
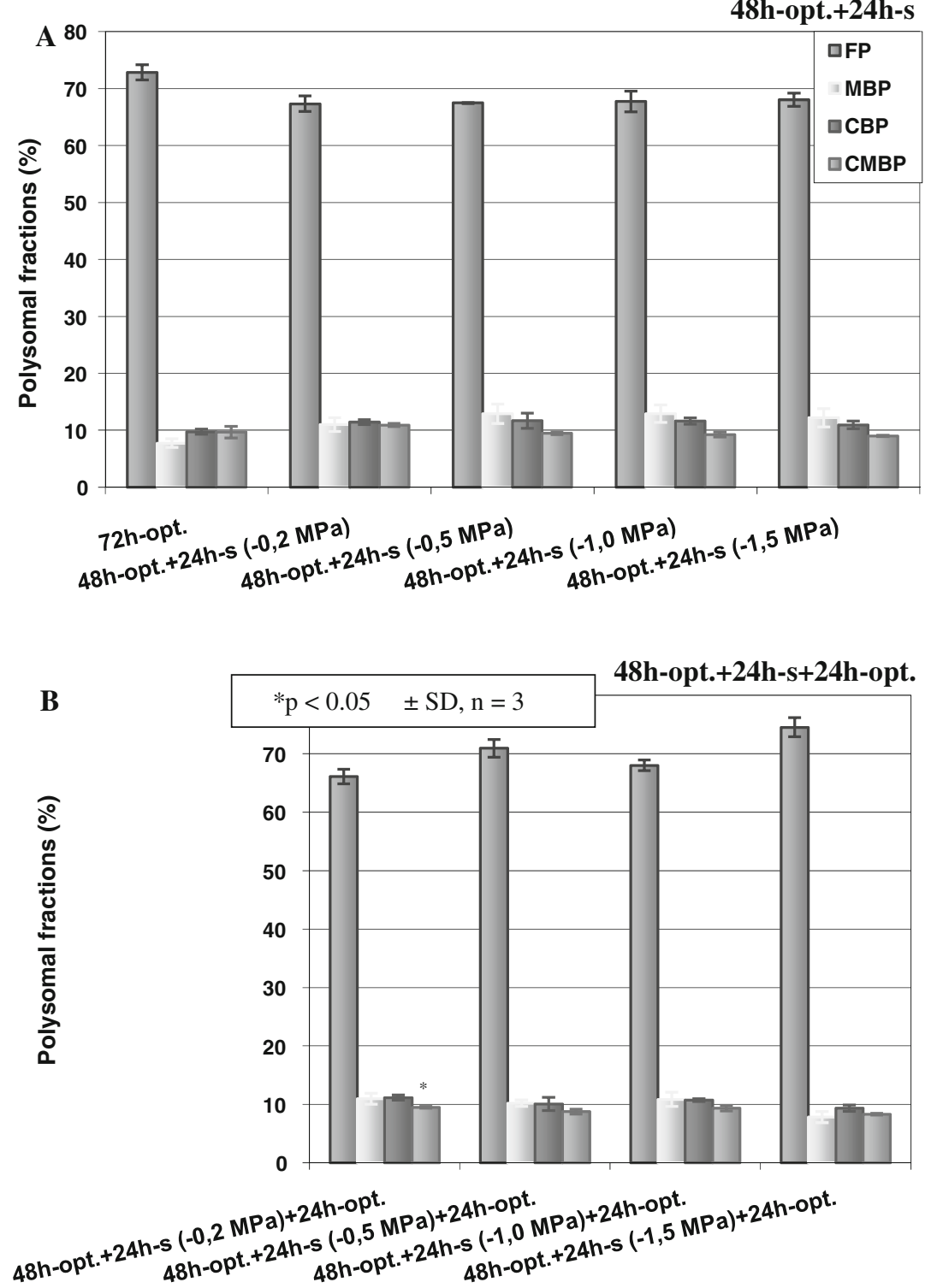

indicated by the research conducted over the past few decades (Costa-Franca et al. 2000; Gill et al. 2002; Gomes et al. 1996; Kosowska et al. 2004; Murillo-Amador et al. 2002; Spyropoulos and Lambiris 1980; Xu and Bewley 1991). Moreover, osmotic stress delays the onset of embryos and sprouts growth (Gill et al. 2002). Similarly to the above findings, in our experiments the long-term osmotic stress retarded germination of pea seeds and growth of embryos, sprouts and early seedlings, proportionately to its intensity. When the intensity of long-term osmotic stress was excessively high $(-1.0$ and $-1.5 \mathrm{MPa})$, germination processes were completely halted. Under the effect of short-term osmotic stress, depressed growth rate of early seedlings were also observed. Growth retardation caused by short-term osmotic stress had been observed previously by Loggini et al. (1999) as well as Keleş and
Öncel (2002). During the recovery after a short-term osmotic stress, the growth of soybean and sorghum seedlings was resumed (Bensen et al. 1988; Gill et al. 2002; Mason et al. 1988). This observation has also been confirmed by the results obtained during the present experiment.

Changes in the growth of soybean under low water potential are associated with the changes in the content of polysomes and polysomal mRNA (Mason et al. 1988). In the present study, it has been verified that the inhibition of seed germination and seedling growth during osmotic stress was accompanied by a depressed level of polysomes in their tissues. The higher the intensity of osmotic stress, the more delayed the formation of polysomes. Decreased shares of polysomes in embryonic tissues have also been observed by Hsiao (1970), Kawaguchi et al. (2003, 2004), Kosowska 
et al. (2004), Mason and Matsuda (1985), Rhodes and Matsuda (1976). It has also been reported that the level of polysomes decreased in embryonic tissues under the influence of ABA (Weidner et al. 2006), high temperature (Rilkey 1981) or oxygen deficit (Bailey-Serres and Freeling 1990). According to Hsiao (1970), a depressed level of polysomes is the earliest metabolic change caused by water stress, leading to such results as decreased rate of protein synthesis or changes in the composition of proteins. Resumed formation of polysomes was also observed in this study during the recovery after short-term osmotic stress, which seems indicative of a large flexibility of young tissues and their large resistance to the influence of water stress. In addition, the more intensive the short-term stress, the faster the recovery rate. According to many authors (Hsiao 1970; Mason and Matsuda 1985; Mason et al. 1988), the increased share of polysomes in embryonic tissues during the recovery period proceeds and increases the rate of plant growth, a finding that was also observed in our study. Noteworthy is the fact that the rate of recovery processes depends on the duration of water stress (Hsiao 1970).

There are four populations of polysomes in plant tissue: FP, MBP, CBP and CMBP. The dominant population in the examined samples exposed to long-term osmotic stress was the FP, whose content of considerably higher than in the control, similarly to CBP and CMBP. In turn, the content of MBP was higher only in the samples treated with osmotic stress of high intensity $(-1.0$ and $-1.5 \mathrm{MPa})$. Similar results regarding the $\mathrm{CBP}$ and $\mathrm{CMBP}$ have been obtained by Kosowska et al. (2004). These results suggest the most intensive synthesis of cytosol proteins (FP population) and less intensive production of proteins responsible for adaptation of plants to stress conditions (CBP and CMBP populations) (Krupińska et al. 2003). On the other hand, proteins protecting plasmatic intercellular membranes against water stress as well as secretory proteins (MBP populations) are synthesized under stress conditions of high intensity (Hesketh and Pryme 1991; Weidner et al. 2000). Under short-term osmotic stress, it is mainly the synthesis of secretory proteins and proteins responsible for acclimatization processes, i.e., stress proteins, which is raised, a finding that is supported by the results obtained during our study. Noteworthy is the fact that during the recovery process after short-term stress, the content of MBP and CBP populations decreased.

The stability of mRNA is affected by a balanced cytoplasmic environment in a plant cell (Brady et al. 1984) and by the type of a tissue in which it occurs (Krupińska et al. 2003). The results of research on mRNA stability presented in this paper indicate that the resistance of mRNA to RNase digestion was higher under stress conditions. The most stable one were polysomes which were connected with membranes and cytoskeleton (CMBP). Graumann et al.
(1997) demonstrated that cold stress induce of cold-shock proteins which maintain mRNA in a state that remains accessible to ribosomes binding. Dense packing of ribosomes on mRNA protect it from nucleolitic attack (Petersen 1992). Furthermore, Davies et al. (1998) showed that the $\mathrm{CBP} / \mathrm{CMBP}$ were maximally loaded within $5 \mathrm{~min}$, whereas the unbound polysomes were loaded more slowly. This implies that initiation of translation was faster with $\mathrm{CBP} / \mathrm{CMBP}$. If elongation and termination of translation were not also faster, this would cause more ribosomes to accumulate on each regions of mRNA. If this is the case, there would be less "unprotected" regions of mRNA in CBP/CMBP than in FP, thus they would not be as sensitive to RNase. This means that in response to stress, plants can synthesize the so-called stress proteins using for this purpose $\mathrm{CBP}$ and $\mathrm{CMBP}$ populations.

Open Access This article is distributed under the terms of the Creative Commons Attribution Noncommercial License which permits any noncommercial use, distribution, and reproduction in any medium, provided the original author(s) and source are credited.

\section{References}

Abe S, Davies E (1991) Isolation of F-actin from pea stems: evidence from fluorescence microscopy. Protoplasma 163:51-61

Abe S, Ito Y, Davies E (1992) Co-sedimentation of actin, tubulin and membranes in the cytoskeleton fractions from peas and mouse 3T3 cells. J Exp Bot 43:941-949

Adams A, Fey EG, Pike SF, Taylorson CJ, White HA, Rabin ER (1983) Preparation and properties of a complex from rat liver of polyribosomes with components of the cytoskeleton. Biochem J 216:215-226

Bailey-Serres J, Freeling M (1990) Hypoxic stress-induced changes in ribosomes of maize seedling roots. Plant Physiol 94:1237-1243

Bensen RJ, Boyer JS, Mullet JE (1988) Water deficit-induced changes in abscisic acid, growth, polysomes, and translatable RNA in soybean hypocotyls. Plant Physiol 88:289-294

Brady CJ, Gibson TS, Barlow EWR, Speirs J, Wyn Jones RG (1984) Salt-tolerance in plants. I. Ions, compatible organic solute and the stability of plant ribosomes. Plant Cell Environ 7:571-578

Costa-Franca MG, Pham Thi AT, Pimentel C, Pereyra Rossiello RO, Zuily-Fodil Y, Laffray D (2000) Differences in growth and water relations among Phaseolus vulgaris cultivars in response to induced drought stress. Environ Exp Bot 43:227-237

Davies E, Abe S (1995) Method for isolation and analysis of polyribosomes. Method Cell Biol 50:209-222

Davies E, Abe S, Larkins BA, Clore AM, Quatrano RS, Weidner S (1998) The role of the cytoskeleton in protein synthesis. In: Bailley-Serres J, Gallie DR (eds) A look beyond transcription: mechanisms determining mRNA stability in plants. American Society of Plant Physiologists, Rockville, pp 115-124

Gill PK, Sharma AD, Singh P, Bhullar SS (2002) Osmotic stressinduced changes in germination, growth and soluble sugar content of Sorghum bicolor (L.) moench seeds. Bulg. J Plant Physiol 28:12-25

Gomes FE, Eneas FJ, Tarquínio PJ (1996) Effects of osmotic stress on growth and ribonuclease activity in Vigna unguiculata (L.) Walp. seedlings differing in stress tolerance. Rev Bras Fisiol Veg 8:51-57 
Gong P, Wilke BM, Strozzi E, Fleischmann S (2001) Evaluation and refinement of a continuous seed germination and early seedling growth test for the use in the ecotoxicological assessment of soils. Chemosphere 44:491-500

Graumann P, Wendrich TM, Weber MH, Schröder K, Marahiel MA (1997) A family of cold shock proteins in Bacillus subtilis is essential for cellular growth and for efficient protein synthesis at optimal and low temperatures. Mol Microbiol 25:741-756

Gualerzi C, Cammarano P (1969) Comparative electrophoretic studies on the protein of chloroplast and cytoplasmic ribosomes of spinach leaves. Biochem Biophys Acta 190:170-186

Hesketh JE, Pryme IF (1991) Interaction between mRNA, ribosomes and the cytoskeleton. Biochem J 277:1-10

Hsiao TC (1970) Rapid changes in levels of polyribosomes in Zea mays in response to water stress. Plant Physiol 46:281-285

Kacperska A (1998) Reakcje roślin na czynniki stresowe. W: Kopcewicz J, Lewak A (red) Podstawy fizjologii roślin, PWN, Warszawa, pp 575-633

Kawaguchi R, Williams AJ, Bray EA, Bailey-Serres J (2003) Waterdeficit-induced translational control in Nicotiana tabacum. Plant Cell Environ 26:221-229

Kawaguchi R, Girke T, Bray EA, Bailey-Serres J (2004) Differential mRNA translation contributes to gene regulation under nonstress and dehydration stress conditions in Arabidopsis thaliana. Plant J 38:823-839

Keleş Y, Öncel I (2002) Response of antioxidative defence system to temperature and water stress combinations in wheat seedlings. Plant Sci 163:783-790

Kosowska M, Frączek E, Amarowicz R, Karamać M, Abe S, Weidner S (2004) Water-deficit-induced changes in cytoskeleton-bound and other polysomal populations in embryonic tissue during triticale caryopsis germination. Acta Physiol Plant 26:67-74

Krupińska S, Weidner S, Frączek E, Amarowicz R (2003) Polysome formation and stability in pea stem and root tissue. Acta Physiol Plant 25:135-141

Loggini B, Scartazza A, Brugnoli E, Navari-Izzo F (1999) Antioxidative defense system, pigment composition, and photosynthetic efficiency in two wheat cultivars subjected to drought. Plant Physiol 119:1091-1099

Mason HS, Matsuda K (1985) Polyribosomes metabolism, growth and water status in the growing tissues of osmotically stressed plant seedlings. Physiol Plant 64:95-104
Mason HS, Mullet JE, Boyer JS (1988) Polysomes, messenger RNA, and growth in soybean stems during development and water deficit. Plant Physiol 86:725-733

Mullet JE, Whitsitt MS (1996) Plant cellular responses to water deficit. J Plant Growth Regul 20:119-124

Murillo-Amador B, López-Aguilar R, Kaya C, Larrinaga-Mayoral J, Flores-Hernández A (2002) Comparative effects of $\mathrm{NaCl}$ and polyethylene glycol on germination, emergence and seedling growth of cowpea. J Agron Crop Sci 188:235-247

Petersen C (1992) Control of functional mRNA stability in bacteria: multiple mechanisms of nucleolytic and non-nucleolytic inactivation. Mol Microbiol 6:277-282

Rhodes PR, Matsuda K (1976) Water stress, rapid polyribosome reduction and growth. Plant Physiol 58:631-635

Rilkey GJP (1981) Effects of high temperature on protein synthesis during germination of maize (Zea mays L.). Planta 151:75-80

Spyropoulos CG, Lambiris MP (1980) Effect of water stress on germination and reserve carbohydrate metabolism in germinating seeds of Ceratonia siliqua L. J Exp Bot 31:851-857

Starck Z (2002) Wpływ stresów abiotycznych na plonowanie roślin. W: Górecki R, Grzesiuk S (red) Fizjologia plonowania roślin, UWM, Olsztyn, pp 447-486

Starck Z, Chołuj D, Niemyska B (1995) Fizjologiczne reakcje roślin na niekorzystne czynniki środowiska. SGGW, Warszawa

Weidner S (2007) Kwasy nukleinowe, synteza białek, regulacja ekspresji genów oraz inżynieria genetyczna. In: Minakowski W, Weidner S (red) Biochemia kręgowców, PWN, Warszawa, pp 258-404

Weidner S, Łukaszewicz D, Amarowicz R (2000) Significant role for polysomes associated with the cytoskeleton in the control of protein synthesis during germination of triticale caryopses in the presence of abscisic acid. Acta Physiol Plant 22:185-193

Weidner S, Każarnowicz M, Frączek E, Amarowicz R, Karamać M (2006) Exogenous abscisic acid increases stability of polysomes in embryos of triticale caryopses during germination. Acta Physiol Plant 28:627-634

Xu N, Bewley JD (1991) Sensitivity to abscisic acid and osmoticum changes during embryogenesis of alfalfa (Medicago sativa). J Exp Bot 42:821-826 